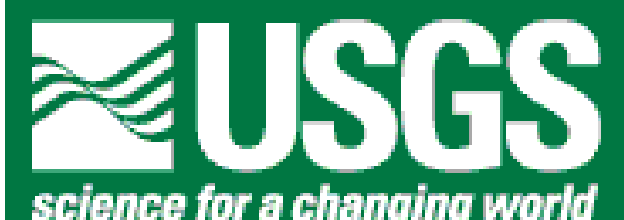

\title{
Dynamics of the Physical Environment at the USS Arizona Memorial: 2002-2004
}

U.S. Department of the Interior

U.S. Geological Survey

Open-File Report 2004-1353

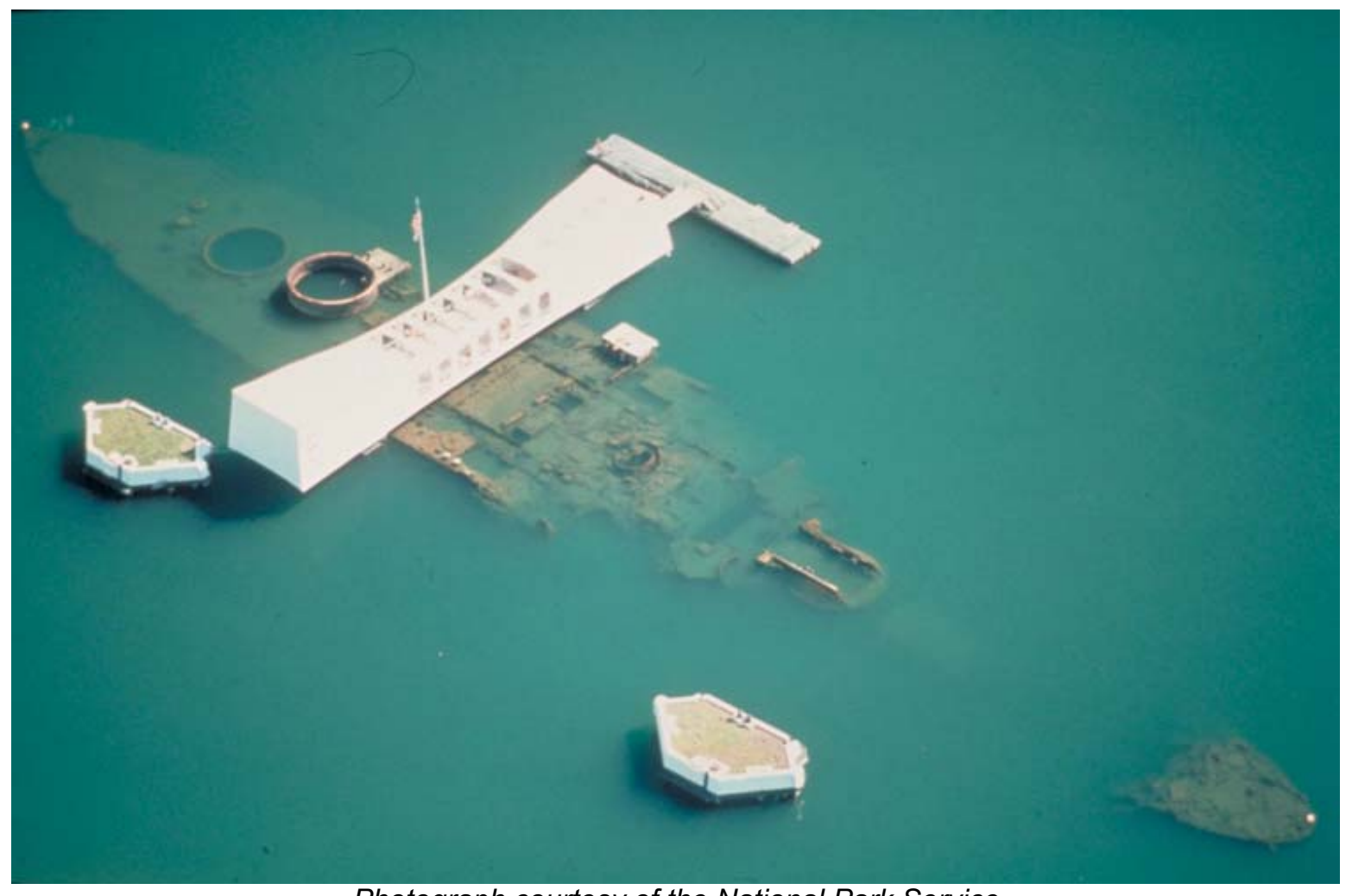

Photograph courtesy of the National Park Service 



\section{Dynamics of the Physical Environment at the USS Arizona Memorial: 2002-2004}

Curt D. Storlazzi ${ }^{1}$, Matthew A. Russell ${ }^{2}$, Marshall D. Owens ${ }^{3}$, Michael E. Field ${ }^{1}$ and Larry E. Murphy ${ }^{2}$

${ }^{1}$ US Geological Survey, Pacific Science Center, Santa Cruz, CA

${ }^{2}$ National Park Service, Submerged Resources Center, Santa Fe, NM

${ }^{3}$ National Park Service, USS Arizona Memorial, Pearl Harbor, Oahu, HI

U.S. GEOLOGICAL SURVEY

Open-File Report 2004-1353 


\section{LIST OF TABLES}

TABLE 1. Experiment personnel.

TABLE 2. Instrument package deployment $\log 11 / 2002-01 / 2004$.

\section{LIST OF FIGURES}

FIGURE 1. Map of the study area location in relation to the main Hawaiian Island chain.

FIGURE 2. Location of instrument packages in the study area.

FIGURE 3. Photographs of instrument packages.

FIGURE 4. Meteorologic forcing during the deployments.

FIGURE 5. Phasing between tides and near-bed $(10 \mathrm{~m})$ flow, acoustic backscatter and particulate flux.

FIGURE 6. Near-bed $(10 \mathrm{~m})$ mean flow and its variability during a deployment.

FIGURE 7. Near-bed $(10 \mathrm{~m})$ and near-surface $(3 \mathrm{~m})$ temperatures and the resulting thermal stratification.

FIGURE 8. Relationship between near-surface $(3 \mathrm{~m})$ temperature and salinity.

FIGURE 9. Phasing between tides and near-surface $(3 \mathrm{~m})$ temperature, $\mathrm{pH}$, oxygenreduction potential and dissolved oxygen.

FIGURE 10. Phasing of temperature, $\mathrm{pH}$, oxygen-reduction potential and dissolved oxygen relative to the time of day and by season.

FIGURE 11. Vertical profiles of temperature, salinity and dissolved oxygen off the USAR dock.

\section{LIST OF APPENDICES}

APPENDIX 1. Sontek Triton Information.

APPENDIX 2. YSI 6600 Sonde Information. 


\section{ADDITIONAL DIGITAL INFORMATION}

For an online PDF version of this report, please see:

http://pubs.usgs.gov/of/2004/1353/

For more information on the U.S. Geological Survey Western Region's Coastal and Marine Geology Team, please see:

http://walrus.wr.usgs.gov/

For more information on the National Park Service's Submerged Resources Center, please see:

http://www.nps.gov/submerged

For more information on the National Park Service's Submerged Resources Center's USS Arizona Memorial Project, please see:

http://data2.itc.nps.gov/submerged/dispproj.cfm?alphacode=USAR

For general information on the USS Arizona National Memorial please see:

http://www.nps.gov/usar/

\section{DIRECT CONTACT INFORMATION}

Regarding this Report

Dr. Curt D. Storlazzi, Oceanographer.

cstorlazzi@usgs.gov

USS Arizona Memorial Project Information

Matthew A. Russell, Project Director: $\quad$ matthew russell@nps.gov

\section{REPORT REFERENCE}

Storlazzi, C.D., Russell, M.A., Owens, M.D., Field, M.E. and Murphy, L.E., 2004.

"Dynamics of the Physical Environment at the USS Arizona Memorial: 2002-2004" U.S. Geological Survey Open-File Report 2004-1353, 28 p. 


\section{INTRODUCTION}

U.S. Geological Survey (USGS) and National Park Service (NPS) personnel collected long-term (14 months), high-resolution physical and chemical oceanographic measurements at the USS Arizona Memorial (USAR) in 2002-2004 to better understand the nature of the environment surrounding the mostly submerged historic ship. Scientists used two bottom-mounted, multi-parameter instruments deployed in water depths less than $10 \mathrm{~m}$ to record critical environmental data. This study supports the National Park Service's Submerged Resources Center (NPS-SRC) research directed at understanding and characterizing the nature and rate of natural processes affecting deterioration of the National Historic Landmark (NHL) USS Arizona. The purpose of these measurements was to collect hydrographic data to better constrain the nature of the physical and chemical environment on the submerged vessel hull and near the Memorial to determine how they vary over the course of a year.

This project represents a multi-agency approach to acquiring sound scientific data requisite for future stewardship-based management actions. Several organizations cooperatively funded this project: USGS, Department of Defense Legacy Resources Management Fund, NPS Systemwide Archeological Inventory Program, USS Arizona Memorial, Arizona Memorial Museum Association, and NPS Submerged Resources Center.

\section{Project Objectives:}

The objective of the instrument deployments was to understand how waves, currents and water column properties such as water temperature, salinity, $\mathrm{pH}$, turbidity, oxygen reduction potential and dissolved oxygen in the vicinity of the Memorial vary over the course of a year. These data were collected to support the NPS-SRC research to understand and characterize the nature and rate of natural processes affecting deterioration of USS Arizona, designated along with USS Utah as NHLs, the nation's highest recognition of historic significance, on May 5,1989 . The project was designed to be multi-year, interdisciplinary and cumulative, with each element contributing to developing an overall management strategy designed to provide the basic research required to make informed management decisions for long-term preservation of these $\mathrm{NHL}$ sites. Understanding these issues is required for sound management decisions regarding long-term preservation of these sites. In addition, this research program will have global application to the many sunken steel heritage vessels, and it will serve as a management model for NPS and partners who have stewardship responsibility for these sites. To meet these objectives, flow and water column properties close to Arizona's hull were investigated. The two instrument packages were deployed over a period spanning 14 months to investigate variability over daily-to-seasonal time scales.

\section{Study Area:}

Instrument deployments were conducted off the northwest corner of Ford Island in the East Loch of Pearl Harbor, South-central Oahu, Hawaii, USA (FIGURE 1). The long-term station measuring waves, tides and currents was deployed in $10 \mathrm{~m}$ of water roughly $25 \mathrm{~m}$ southeast of Arizona's port beam below the Number 1 turret; in November 2003 it was re-deployed in $10 \mathrm{~m}$ of water roughly $25 \mathrm{~m}$ northwest of Arizona's starboard beam below the Number 1 turret (FIGURE 2). The seafloor at these sites was an 


\section{ZUSGS}

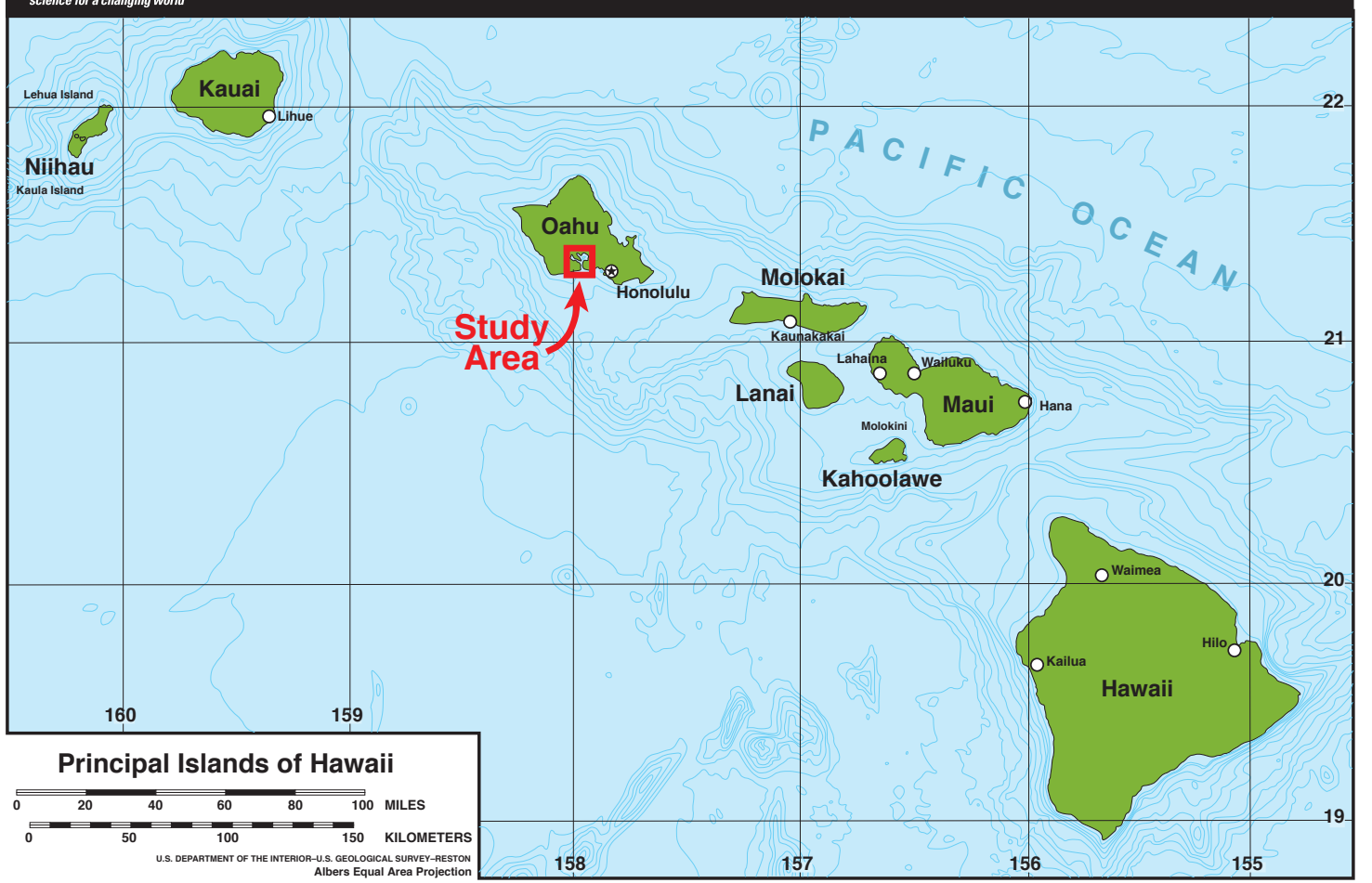

b)

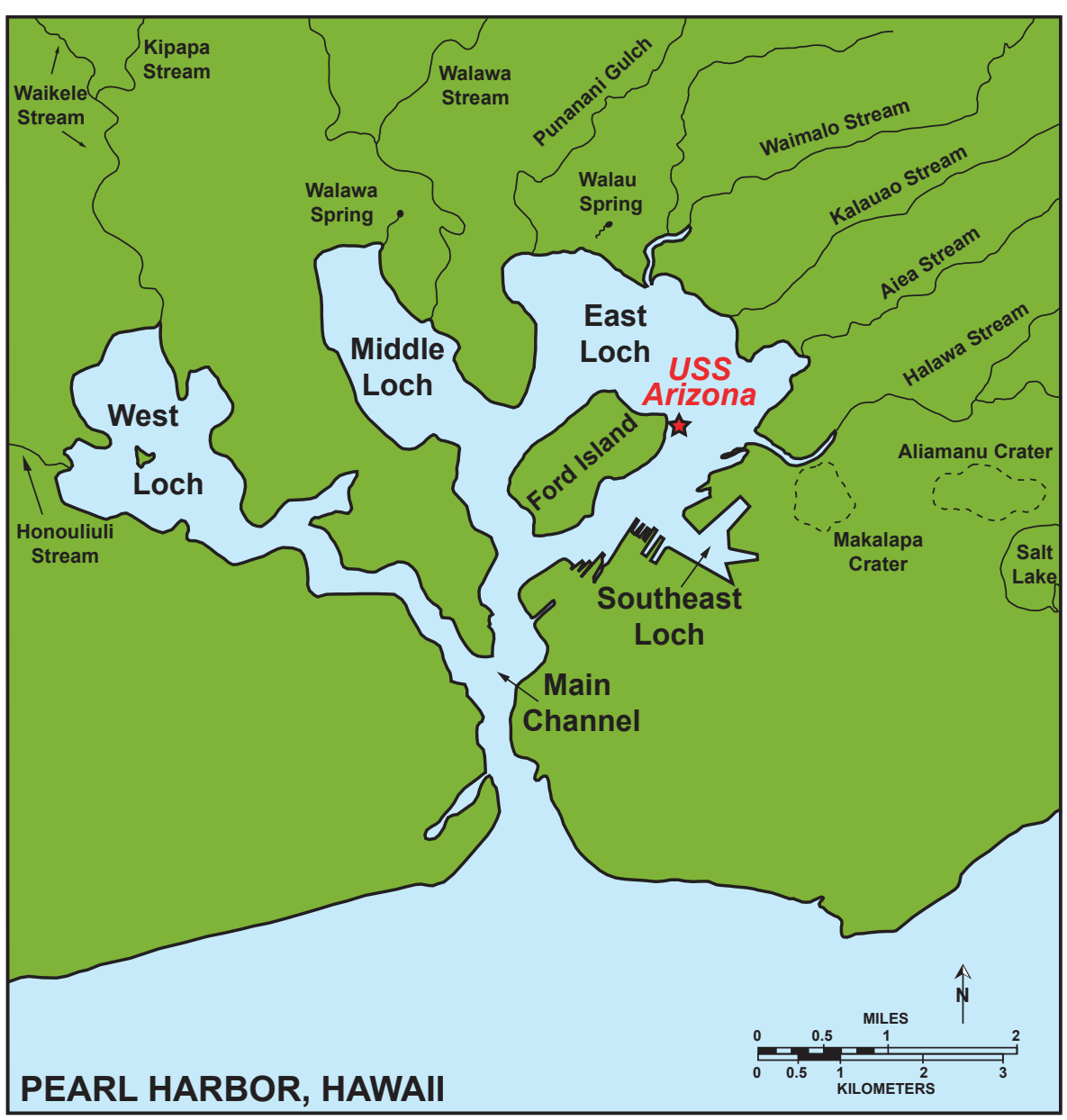

FIGURE 1. Map of the study area. a) Location of Pearl Harbor in relation to the main Hawaiian Island chain. b) Location of the USAR in Pearl Harbor relative to Ford Island, the main Lochs and sources of freshwater that empty into the harbor. 


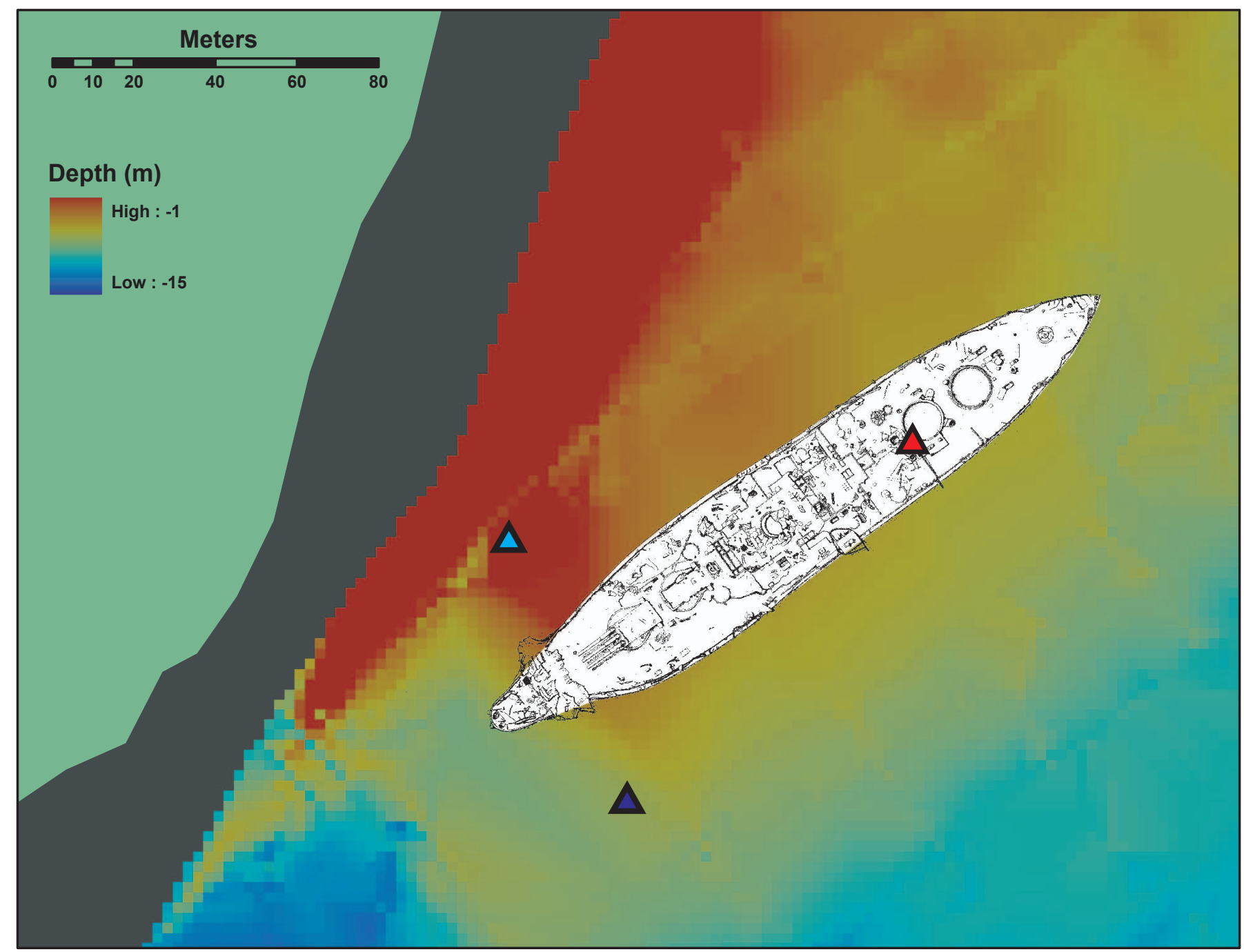

b)

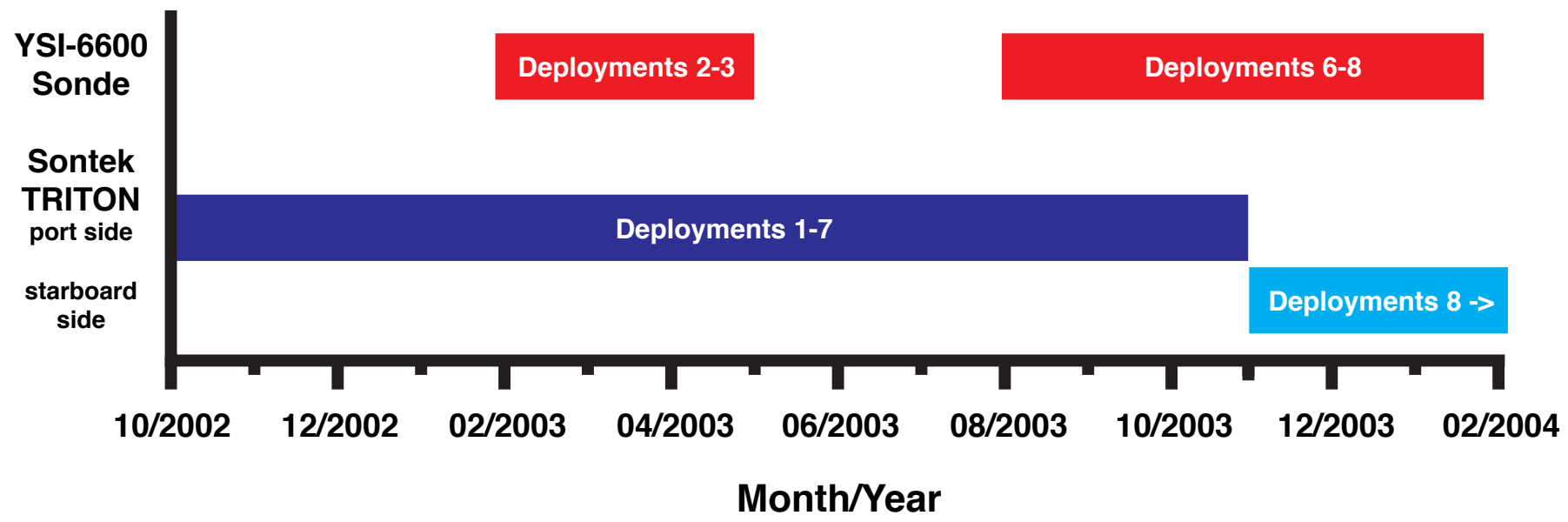

FIGURE 2. Spatial and temporal distribution of instrument packages in the study area. a) Map of instrument locations relative to the USAR's hull and Ford Island. b) Instrument deployment timelines. The colors of the timelines correspond to the instrument locations displayed in part "a". 
organic-rich, very well sorted fine silt/mud. The second instrument station, which measured the physical environment, was deployed amidships on Arizona's main deck just forward of the Number 3 barbette and just aft of the Memorial. All diving, mobilization and demobilization were based from the USAR dock on the eastern side of the East Loch of Pearl Harbor, South-central Oahu, Hawaii.

\section{OPERATIONS}

This section provides information about personnel, equipment and vessels used during equipment deployments. See TABLE 1 for personnel involved in this experiment and TABLE 2 for complete deployment information.

\section{Equipment and Data Review:}

Two primary instruments acquired data during the deployments. The first instrument was a SonTek Triton wave/tide gauge. The primary sensor on this package is an upward-looking $10 \mathrm{MHz}$ Acoustic Doppler Velocimeter (ADV), which collects threedimensional single-point measurements of current velocity and acoustic backscatter data (FIGURE 3a). A pressure sensor on the Triton measured tide data that was combined with the ADV data to measure direction wave spectra. The Triton employed two different sampling schemes: First, it sampled the mean currents by averaging the current speeds over a 1-min window every $10 \mathrm{~min}$. Second, it sampled the surface wind waves by collecting current and water depth data over an 8.5-min window every 2 hours. The second primary instrument employed was an YSI 6600 Multiparameter Sonde (FIGURE 3b). The YSI Sonde collected single-point measurements on water temperature and salinity, $\mathrm{pH}$, dissolved oxygen and oxygen-reduction potential when deployed on the hull $3 \mathrm{~m}$ below the surface; the YSI was also used in profiling mode, collecting vertical profiles of water temperature and salinity, $\mathrm{pH}$, dissolved oxygen and oxygen-reduction potential.

The instrument packages were typically deployed for approximately one- to twomonth periods, as limited by the power consumption and sensor sampling rates. The instrument package deployment and recovery log is presented in TABLE 2. The instrument specifics and sampling schemes are listed in APPENDIX 1 for the SonTek Triton and APPENDIX 2 for the YSI 6600 Sonde. When used in profiling mode, the YSI was lowered from the surface to the seafloor in the early morning and the late afternoon for three consecutive days. During these profiles all the sensors on the YSI sampled at once per second. Daily data on meteorologic forcing over the study period were recorded at the Honolulu International Airport roughly $5 \mathrm{~km}$ southeast of the study site. These digital data were downloaded and compiled from NOAA's National Climate Data Center's website (http://www.ncdc.noaa.gov/oa/climate/climatedata.html).

\section{Deployment/Recovery Operations:}

The US Navy operates launches to transport visitors between USAR headquarters and the Memorial about every 15 minutes. These navy launches transported project scientists and instruments to the USAR Memorial dock. Prior to installation of the SonTek Triton, diving scientists established a secure guideline from Arizona's hull out to the location where it would be deployed. The Triton and its semi- 
a)

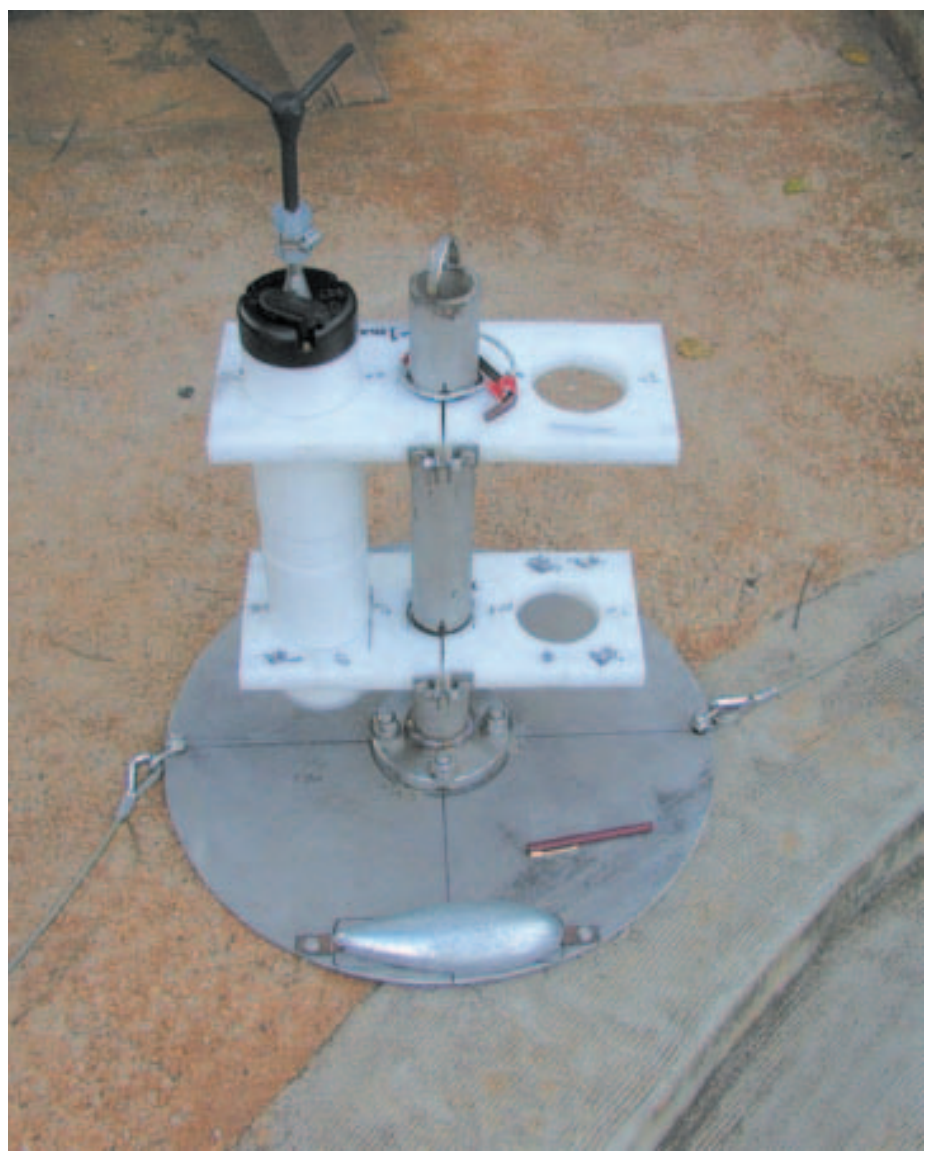

b)

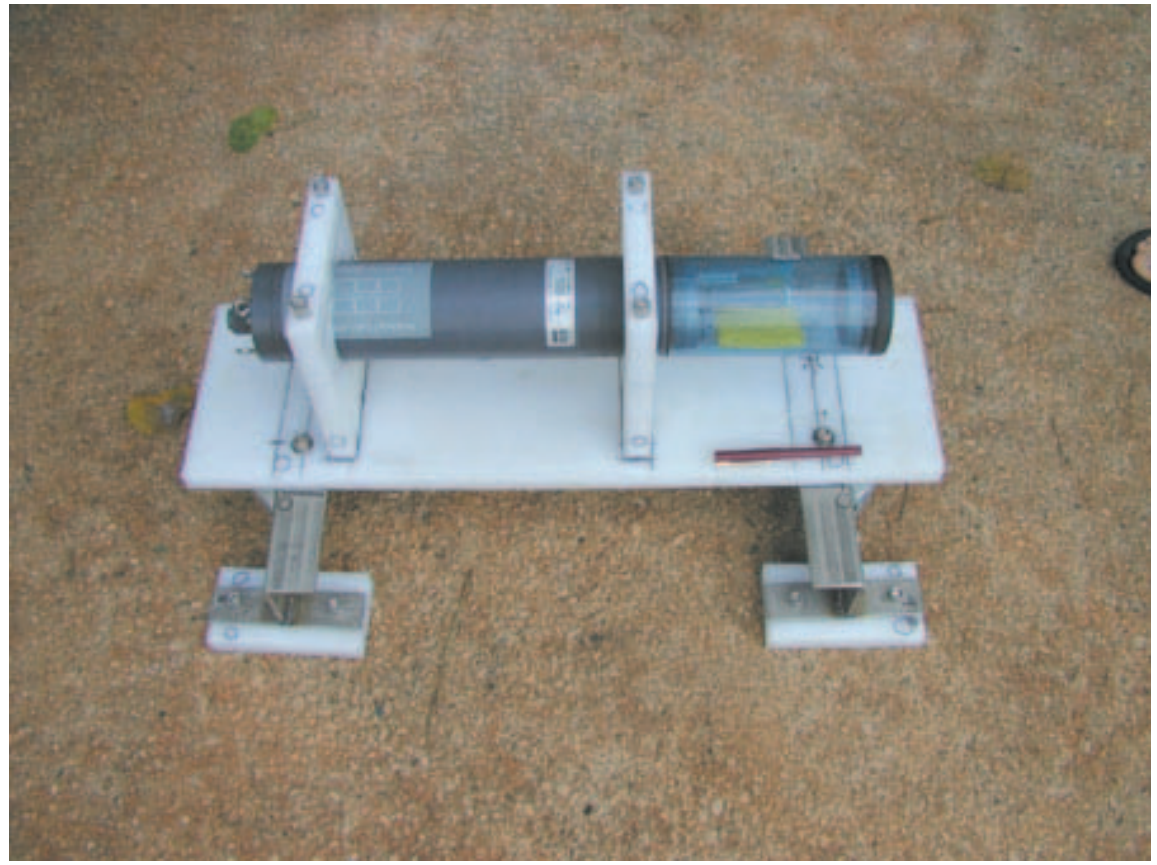

FIGURE 3. Photographs of instrument packages and their mounts. a) The Sontek Triton sensor and sea bed mount. This mount was designed to be able to simultaneously deploy the YSI 6600 Sonde in the empty bracket on the right side of the photograph. b) The YSI 6600 Sonde and hull mount. Note the red pen in both photographs for scale. 
permanent mount were initially deployed by lowering it just below the water's surface where scuba divers attached a lift bag and detached the lifting line. The divers followed a marker line to the sea floor to move the instrument package into place. The divers secured the instrument package with cables attached to sand anchors embedded in the seafloor. Recovery and redeployment operations involved the same procedures.

The vertical profiles collected with the YSI were done from the USAR dock.

These entailed lowering the YSI to just below the surface for a minute to allow all of the sensors to equilibrate, then slowly lowering the YSI from the surface, down to the sea floor, then bringing it slowly back up to the surface.

\section{DATA ACQUISITION AND QUALITY}

Data were acquired on 362 days during the 14-month period between November 2002 and January 2004, for more than $85 \%$ data coverage over the entire experiment period. Instrument refurbishment and battery failure accounted for the 64 days during these 14 months that no data were recorded.

The SonTek Triton produced almost 77,750 observations from each sensor. Data quality was generally very high. Scientists archived the raw Triton data, and copies of the data were post-processed to remove spurious data whenever the beam correlation dropped below $70 \%$. The post-processed data were saved and copies were de-sampled to hourly intervals to better visualize longer-term variability; these desampled copies of the data were also saved and archived.

The YSI 6600 Sonde produced data on 59\% of days deployed (215 out of 362), which resulted in just over 23,000 observations from each sensor. Data quality was generally good, exceptions were from improperly calibrated sensors or when fouled by biologic growth. The post-processed data were saved and copies were de-sampled to hourly intervals to better visualize longer-term variability; these de-sampled copies of the data were also saved and archived.

Six vertical profiles were collected using the YSI 6600 Sonde, with $100 \%$ data recovery from the temperature, conductivity, and dissolved oxygen sensors. Due to sensor malfunction, no $\mathrm{pH}$ or oxygen-reduction potential data were recorded during any of the six profiles.

\section{RESULTS AND DISCUSSION}

This section reviews data collected by both systems during deployments and addresses significance of the findings to characterizing local oceanographic conditions in the study area.

\section{Meteorologic Forcing}

The Hawaiian Islands, situated at roughly $21^{\circ}$ North, are in the Trade wind belt. Consequently, the study area is dominated by very low wind variability during the summer periods when the Trade winds blow consistently; insolation (solar heating) and thus air temperatures are high and precipitation is low (FIGURE 4). During the winters, when extratropical lows and frontal systems propagate through the Hawaiian Islands causing precipitation, weaker and more variable winds, decreased insolation and, thus, 

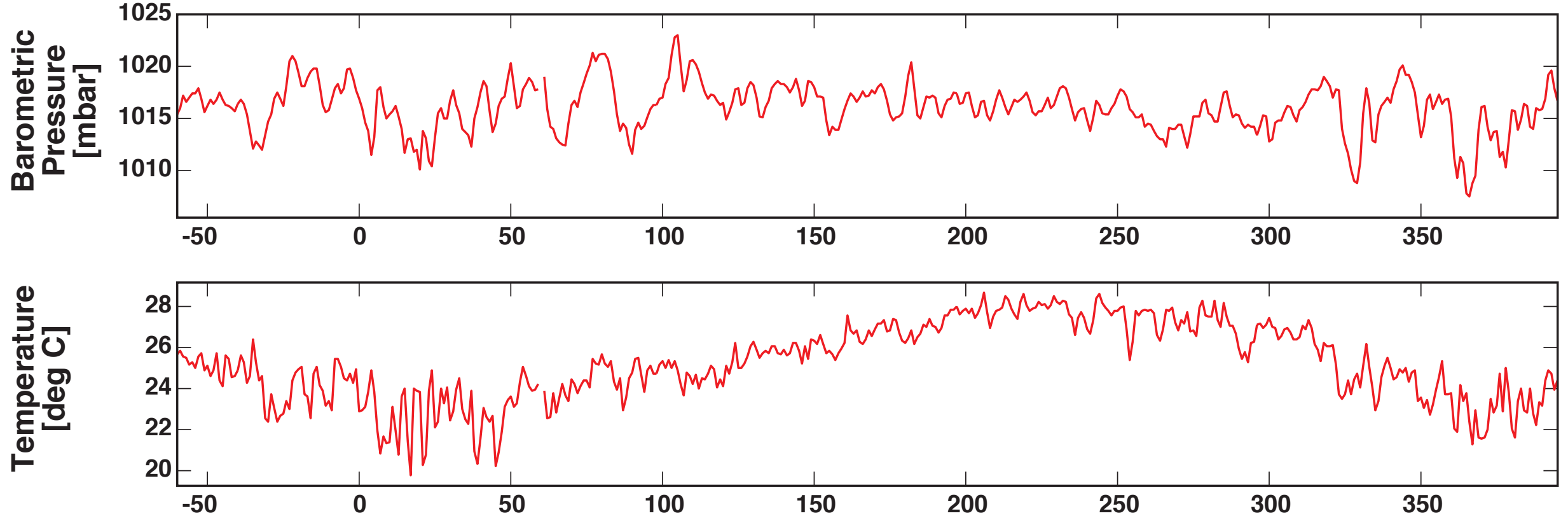

을

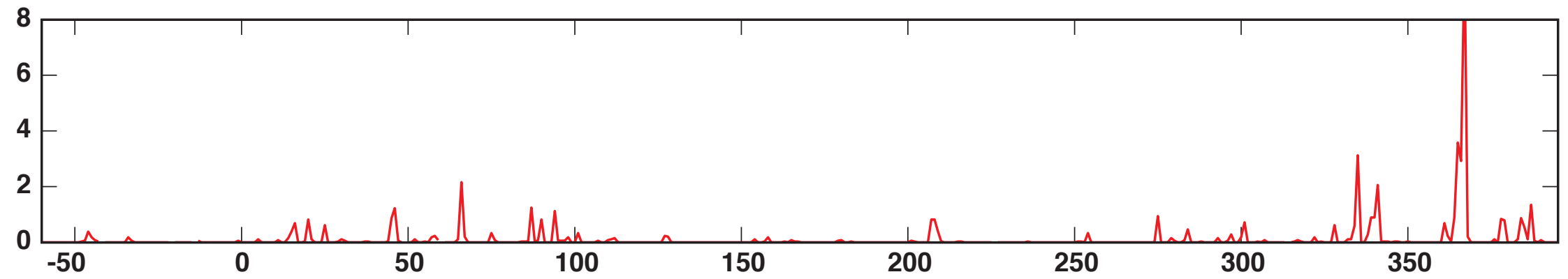

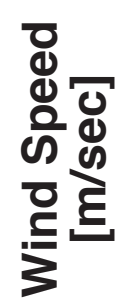

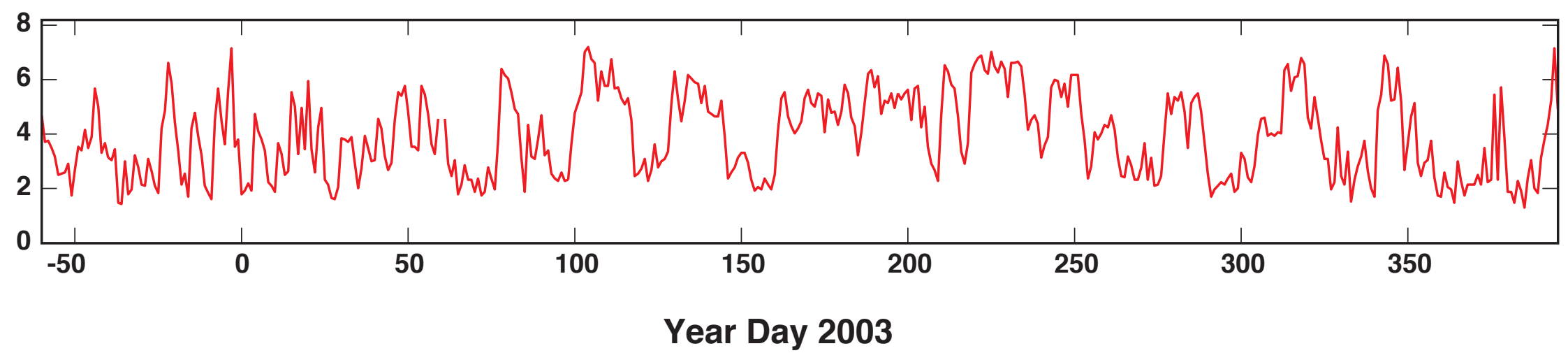

FIGURE 4. Meteorologic forcing from the Honolulu International Airport for the time period 11/2002 through 01/2004. Note the variability between the spring/summer/fall Trade wind-dominated period (YD 60-300) and the winter storm periods. 
lower air temperatures occur. Based on oceanographic measurements made at USAR, decreased air temperatures and precipitation typically reduce water temperature and salinity in Pearl Harbor. The Trade winds, which generally cause the highest sustained wind speeds (excluding tropical cyclones) during the spring, summer and fall, are topographically steered around the Koolau Range to the east of Pearl Harbor, often approaching the south shore of Oahu from the south or southeast and resulting in strong winds to the north or northwest over USAR. During the winter months, passage of fronts and extratropical lows to the north of the Hawaiian Islands results in strong northerly winds being funneled south between the Waianae Range to the west of Pearl Harbor and the Koolau range to the East, resulting in strong winds to the south over USAR. These winds can drive surface currents and cause mixing of the water column at USAR.

\section{Tides}

Pearl Harbor tides are of the mixed, semi-diurnal type with two uneven high tides and two uneven low tides per day; thus the tides change just over every 6 hours (FIGURE 5). The mean daily tidal range during the study was roughly $0.6 \mathrm{~m}$, while the minimum and maximum daily tidal ranges are $0.4 \mathrm{~m}$ and $0.9 \mathrm{~m}$, respectively.

\section{Waves}

Waves in Pearl Harbor during the study were generally extremely small, with significant wave heights $\left(H_{\text {sig }}\right)$ on the order of cm's, with a range of $0.01 \mathrm{~m}$ to $0.08 \mathrm{~m}$ and a mean $H_{s i g} \pm$ one standard deviation of $0.03 \pm 0.01 \mathrm{~m}$. Dominant wave periods $\left(T_{d}\right)$ are in a very narrow range between 19.85 and $20.38 \mathrm{sec}$, with a mean $T_{d} \pm$ one standard deviation of $20.19 \pm 0.08 \mathrm{sec}$; these low height, long period waves all were observed to come out of the southern quadrant $\left(160^{\circ}-200^{\circ}\right)$. This narrow band range and corresponding low wave heights suggest that the pressure sensor along the $10-\mathrm{m}$ isobath is at or near its resolution limits relative to the incident wave frequency. Because the depth of penetration of wave-induced pressure fluctuations and orbital motions decreases exponentially with depth and is dependant on wave height and period, it appears that the SonTek Triton pressure sensor is only able to resolve longer period motions at these small wave heights. Thus, the shorter period wind waves typically observed in the afternoon when the Trade winds are blowing $10-20 \mathrm{~m} / \mathrm{sec}$ are too small in height and too short in period for the pressure sensor to resolve from its depth of $10 \mathrm{~m}$. The 20-sec period waves that are resolvable by the pressure sensor are likely long period ground swell (North Pacific winter swell or South Pacific summer swell) that has enough energy to propagate up the entrance channel of Pearl Harbor and into the East Loch past USAR.

In addition to these natural small, long-period swells, the pressure sensor record was often overwhelmed by high-amplitude, short-period (2-8 sec) modulations. These modulations appear to be due to large vessels passing over or by the Sontek instrument package, for they are anomalously large and have southeasterly $\left(90^{\circ}-150^{\circ}\right)$ or northwesterly $\left(270^{\circ}-330^{\circ}\right)$ directions, likely the result of incident waves and wave reflected off Arizona's hull, respectively. 

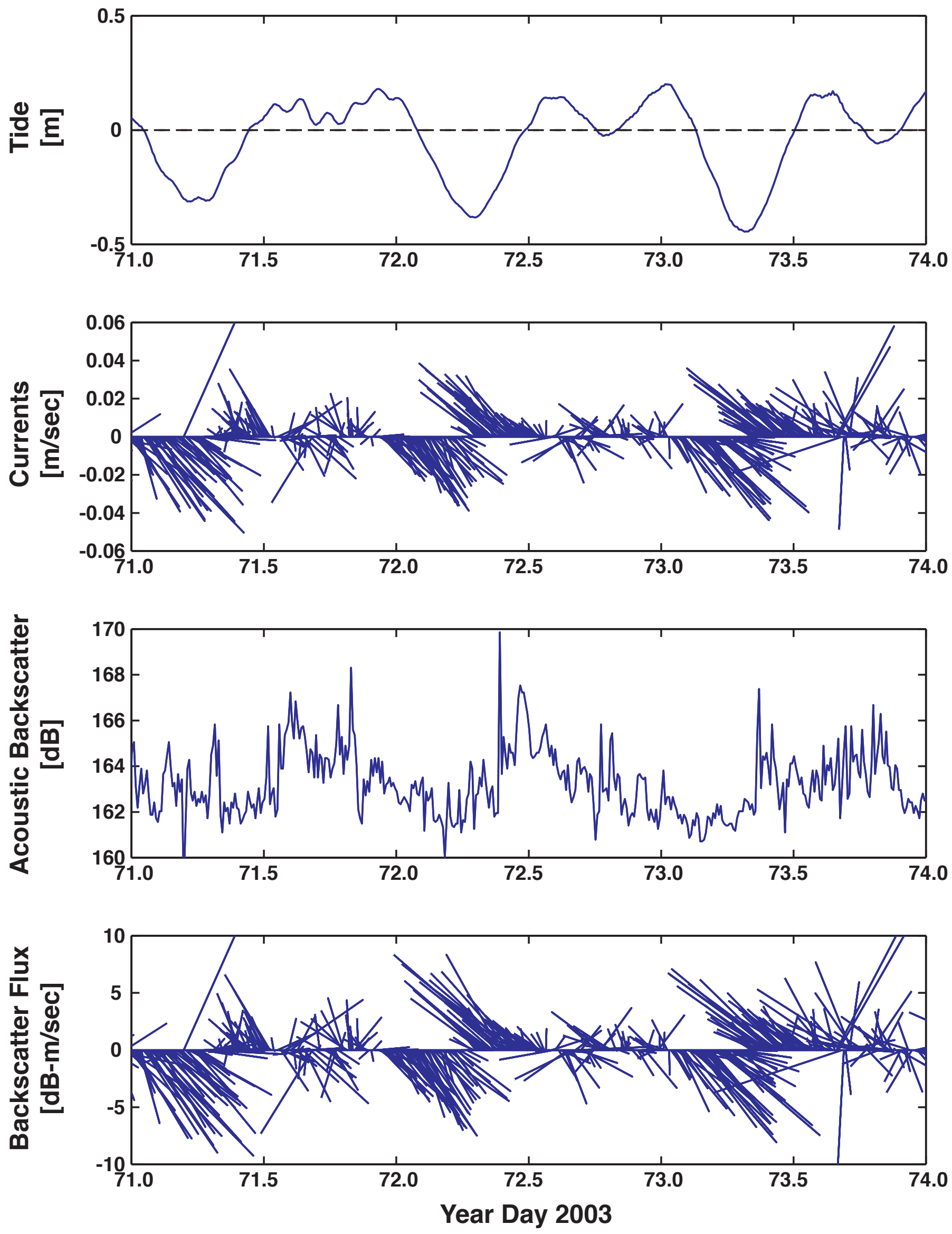

FIGURE 5. Phasing between tides and near-bed $(10 \mathrm{~m})$ flow, acoustic backscatter and particulate flux. Note the tide ebbs to the southeast and floods to the northwest while the acoustic backscatter appears to be greater in the afternoons. 


\section{Currents}

Most daily variability in current speed and direction at the study site are due to the semi-diurnal (12.4 hour) and diurnal (24.8 hour) tides. As the tide rises (floods), currents in Pearl Harbor flow to the northwest towards Arizona; conversely, as the tide falls (ebbs), the currents flow to the southeast roughly orthogonally away from the hull. Mean current speeds \pm one standard deviation are $0.020 \pm 0.015 \mathrm{~m} / \mathrm{sec}$ with a range of $0.001 \mathrm{~m} / \mathrm{sec}$ to $0.122 \mathrm{~m} / \mathrm{sec}$ along the $10-\mathrm{m}$ isobath off the port (southeastern) side of the hull (FIGURES 5-6). The orientation of greatest flow variability and mean flow is oriented orthogonal to the hull and Ford Island, almost orthogonal to the southwestnortheast trend of the East Loch. These observations are unexpected-one would generally assume that flow would be parallel to the Arizona's hull and Ford Island. However, observers confirmed these flow patterns during each instrument deployment on both sides of the ship's hull. Mean current speeds at the site along the 10-m isobath off the starboard (northwestern or Ford Island) side of Arizona's hull were slightly lower, $0.012 \pm 0.013 \mathrm{~m} / \mathrm{sec}$ with a range of $0.001 \mathrm{~m} / \mathrm{sec}$ to $0.094 \mathrm{~m} / \mathrm{sec}$. Net flow over the study's duration was to the southeast at roughly $0.002 \mathrm{~m} / \mathrm{sec}$. Assuming flow remained constant through this section of Pearl Harbor, the mean current speed measured along the $10-\mathrm{m}$ isobath of $0.002 \mathrm{~m} / \mathrm{sec}$ would result in a total replacement of water along the $185-m$ length of the hull in just over 25.7 hours. Because oscillatory tidal flows enhance these mean flow speeds, the actual replenishment time would typically be shorter.

The lunar tidal cycle drives the magnitude of the tidal currents, with the highest tidal current speeds occurring during the spring tides (new and full moons) and the weakest during the neap tides (quarter moons). While tides control the majority of the variability in current speed and direction, insolation-driven Trade wind intensification also appears to slightly influence daily variability. When the Trade winds blow at high speed in the early to late afternoon, the net flow at the 10-m site appears to take on a more northwesterly component. This shift might be due to the Trade winds blowing obliquely onshore to the northwest along Oahu's southern shoreline, which forces oceanic water up into Pearl Harbor. We do not have information at this time that indicates which process or combination of processes is responsible for the observed intensification of northeasterly flow during the afternoon.

\section{Water Column Properties}

The water column properties collected included, with units in parentheses, variations in acoustic backscatter $(\mathrm{dB})$, temperature $\left({ }^{\circ} \mathrm{C}\right)$, salinity $(\mathrm{PSU}), \mathrm{pH}$, dissolved oxygen ("DO", \%) and oxygen-reduction potential (“ORP”, mV). Their ranges, variability and potential causes for their variability are discussed here.

\section{Acoustic Backscatter:}

Over the period of study, the acoustic backscatter, which is a function of the particulate matter in the water column, $0.6 \mathrm{~m}$ above the seabed at the site along the 10$\mathrm{m}$ isobath ranged between $145.48 \mathrm{~dB}$ and $281.52 \mathrm{~dB}$, with a mean backscatter \pm one standard deviation of $179.86 \pm 20.64 \mathrm{~dB}$. In general, highest acoustic backscatter measurements occurred during winter months and the lowest during the summer months. This peak in acoustic backscatter suggests that wintertime phenomena causes increased particulate matter concentrations in the area around USS Arizona. Potential 


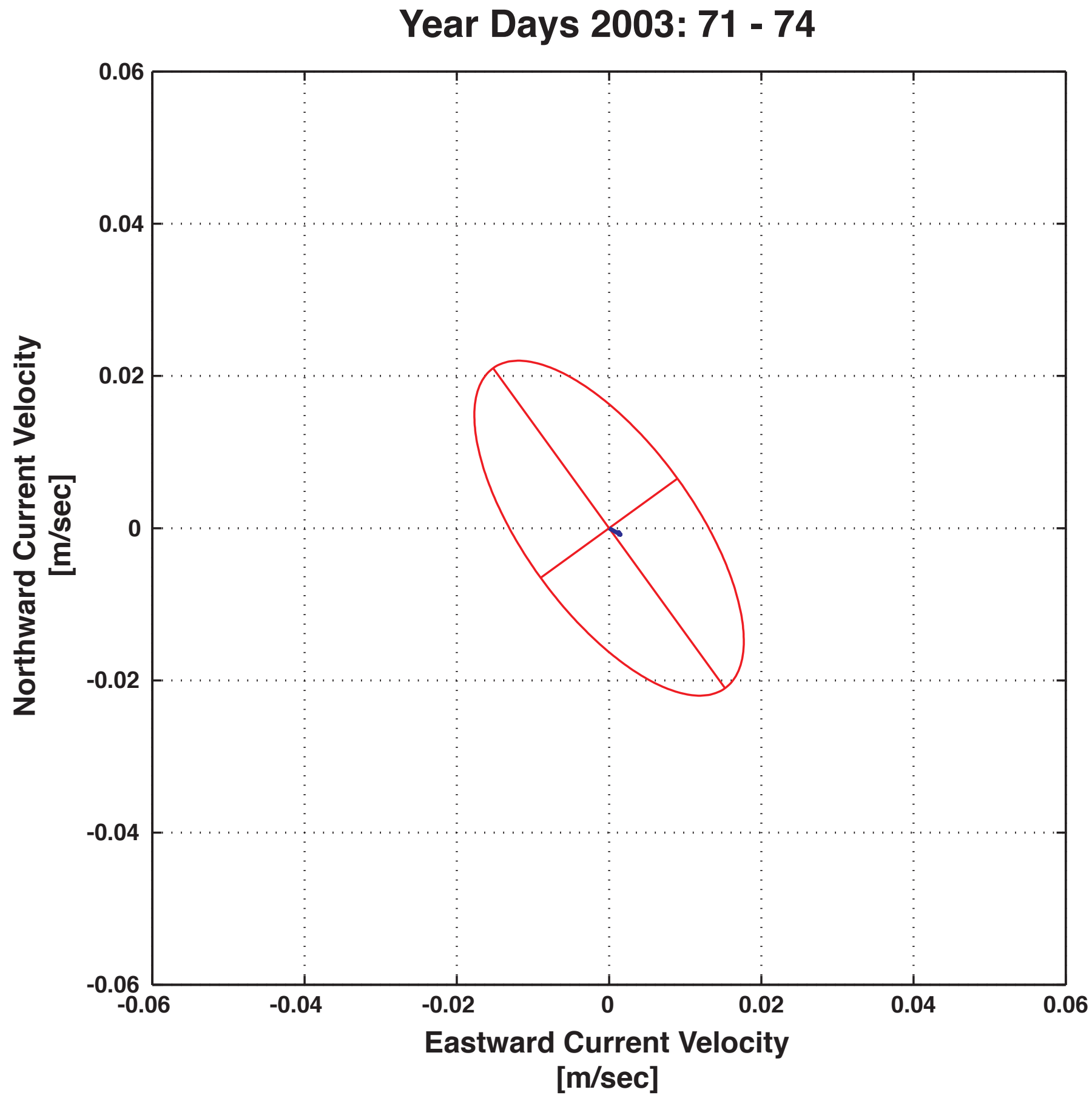

FIGURE 6. Near-bed $(10 \mathrm{~m})$ mean flow and its variability during a deployment. Note the major axis of the current ellipse and mean flow is oriented orthogonal to the USAR's hull and Ford Island, almost orthogonal to the southwest-northeast trend of the East Loch. 
reasons for this increase in backscatter include: precipitation and runoff in other regions of Pearl Harbor that would introduce fine-grained particulate matter into the harbor that is advected into the area around USAR, or nutrients introduced into Pearl Harbor from runoff might cause algal blooms that increase acoustic backscatter.

Acoustic backscatter was generally higher when the flow was to the south, likely caused by fine particulate matter being drawn down from the shallow regions of the northern half of the harbor. Acoustic backscatter also appeared to slightly increase during the early to mid-afternoon and decrease through the night (FIGURE 5); this suggests that either: (a) daily insolation-induced Trade wind intensification during the day creates larger Trade wind-driven waves that suspend more fine-grained sediment that is then advected by the sensor, or (b) more vessel traffic and prop wash during the day in the harbor tends to suspend more of the fine-grained bed sediment, which settles during the evening and night when vessel traffic subsides. We do not have information at this time that indicates which process or combination of processes is responsible for the observed intensification of acoustic backscatter during either the wintertime or in the afternoons and evenings.

\section{Temperature:}

Over the period of study, water temperatures at the site along the $10-\mathrm{m}$ isobath ranged between $23.14{ }^{\circ} \mathrm{C}$ and $27.52{ }^{\circ} \mathrm{C}$, with a mean temperature \pm one standard deviation of $26.03 \pm 1.17^{\circ} \mathrm{C}$. At the shallower instrument location, the water temperatures at the site along the $3-\mathrm{m}$ isobath ranged between $29.42^{\circ} \mathrm{C}$ and $19.15^{\circ} \mathrm{C}$, with a mean temperature \pm one standard deviation of $24.55 \pm 2.08^{\circ} \mathrm{C}$. At both sites, insolation typically warmed the water, often more than $0.7^{\circ} \mathrm{C}$ atop Arizona's hull at the YSI instrument site, but only $0.2-0.3^{\circ} \mathrm{C}$ along the $10-\mathrm{m}$ isobath at the SonTek instrument site. Thermal stratification, measured as the temperature difference between the YSI's temperature sensor on the hull (depth 3 $\mathrm{m}$ ) and the SonTek's temperature sensor along the $10-\mathrm{m}$ isobath, ranged between 0 and $2.5^{\circ} \mathrm{C}$, which reflects a distinct thermocline in the harbor's waters (FIGURE 7). This general trend of warmer water overlying cooler near-bed water causes the water column to be thermally stratified and stable, reducing interaction of the near-bed waters with the surface waters due to density contrasts.

\section{Salinity:}

Over the period of study, the salinity at the site along the 3-m isobath ranged between 16.78 PSU and 42.56 PSU, with a mean salinity \pm one standard deviation of $34.33 \pm 4.25$ PSU. Salinity tended to correlate positively with water temperature (FIGURE 8). This correlation is clearly seen when probable large surface runoff or groundwater effluences are advected by the YSI Sonde during the winter months, causing the temperature and salinity to rapidly drop. Gradual increases back to preevent levels over the course of a few days, likely due to current-induced mixing, follow these sharp decreases.

$\mathrm{pH}$ :

Over the period of study, water $\mathrm{pH}$ at the site along the 3-m isobath ranged between 7.60 and 9.10 , with a mean $\mathrm{pH} \pm$ one standard deviation of $8.04 \pm 0.15$. Most 

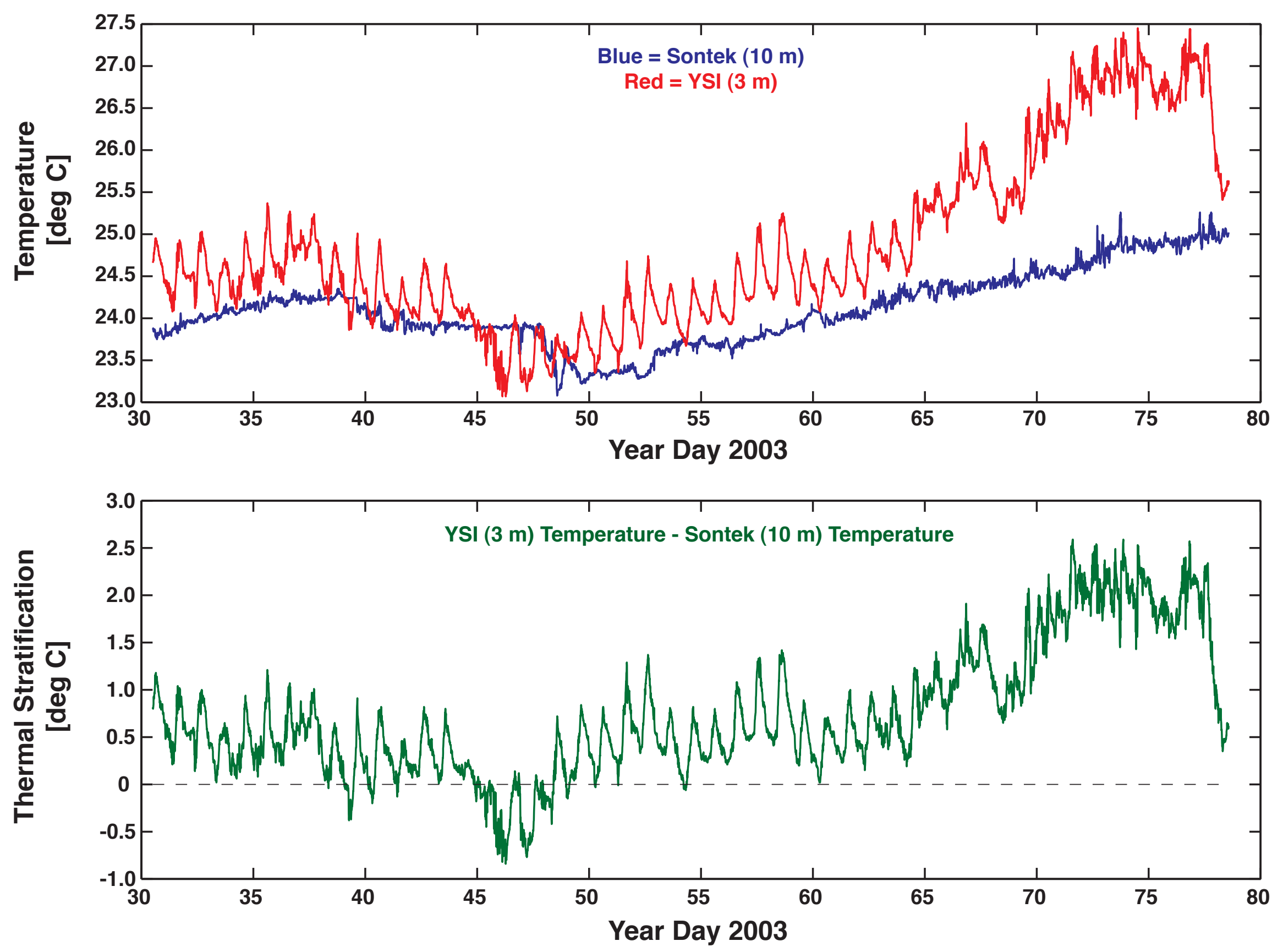

FIGURE 7. Near-bed $(10 \mathrm{~m})$ and near-surface $(3 \mathrm{~m})$ temperatures and the resulting thermal stratification. While both near-bed and near-surface temperatures both follow the same long-term trends, note the greater daily fluctuations in the near-surface temperatures and how they are, in general, much warmer than the near-bed temperatures. This general trend of warmer water overlying cooler near-bed water causes the water column to be thermally stratified and stable, reducing interaction of the near-bed waters with the surface waters due to density contrasts. 


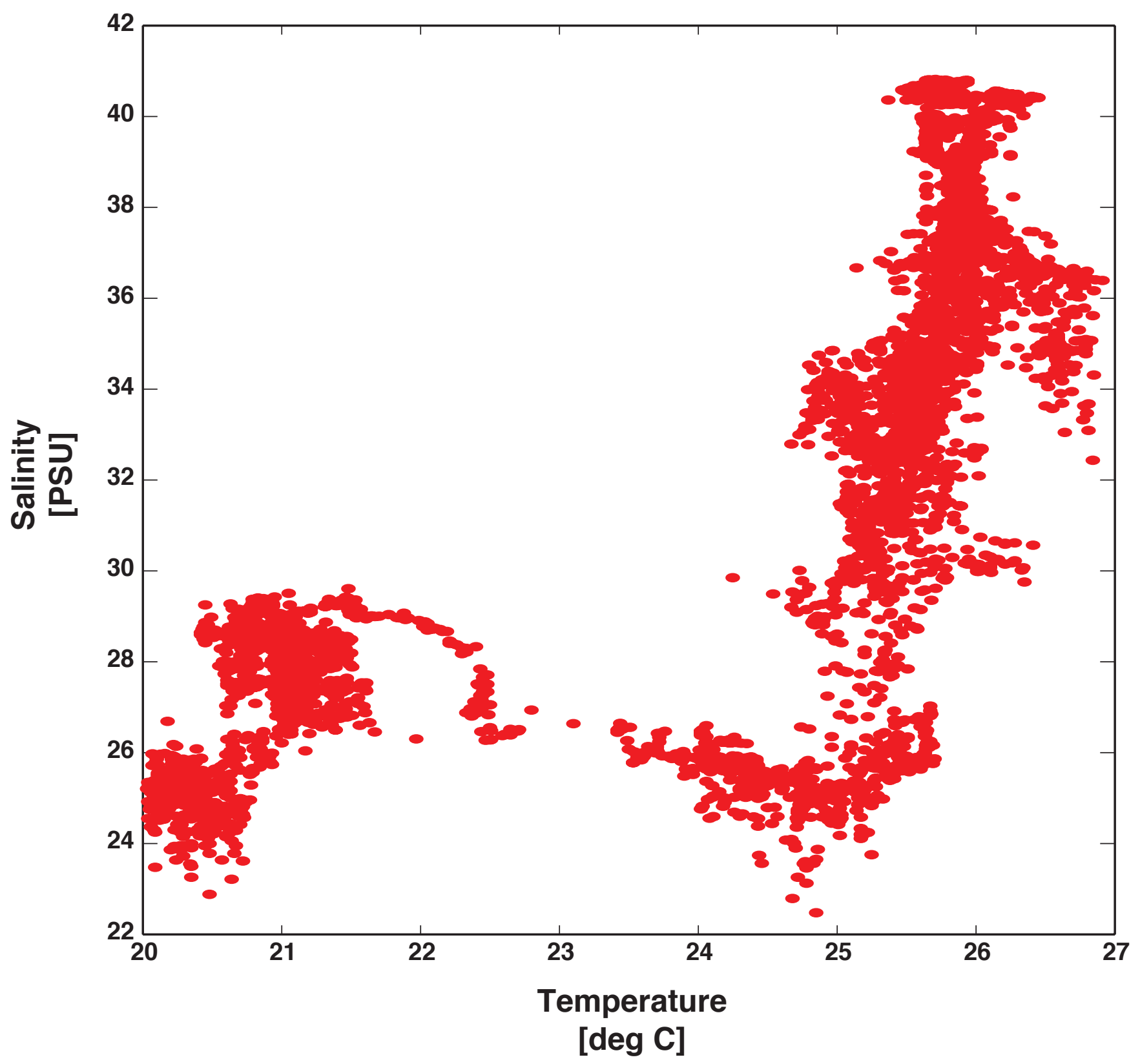

FIGURE 8. Relationship between near-surface $(3 \mathrm{~m})$ temperature and salinity. Note the positive relationship between these two parameters, which is typical of a water mass. The great offset, however, in salinity between $22{ }^{\circ} \mathrm{C}$ and $24^{\circ} \mathrm{C}$ suggests that another lower temperature and salinity water mass was introduced into the Harbor, likely due to precipitation that occurred during the deployment. 
variability in $\mathrm{pH}$ is at daily timescales; $\mathrm{pH}$ tends on average to rapidly increase from approximately 7.9 at roughly 09:00 each morning to more than 8.1 around $13: 00$, then decrease down to nominal levels of 7.9 by $21: 00$ (FIGURES 9-10). This daily increase, which is often on the order of 0.05 to 0.35 , suggests that $\mathrm{pH}$ levels at the study site are related to daily insolation-driven warming or insolation-driven Trade wind intensification and Trade-wind wave-induced mixing.

\section{Dissolved Oxygen:}

Over the period of study, the dissolved oxygen levels in the water at the site along the 3-m isobath ranged between $0 \%$ and $288.5 \%$, with a mean dissolved oxygen level \pm one standard deviation of $69.5 \pm 58.8 \%$. Similar to the $\mathrm{pH}$ levels, most variability in dissolved oxygen levels is at daily timescales; dissolved oxygen tends to rapidly increase at roughly 09:00 each morning, peak around 13:00, then decrease down to nominal levels by 21:00 (FIGURES 9-10). This daily increase of 5-20\% suggests that dissolved oxygen levels at Arizona are related to daily insolation-driven warming or insolation-driven Trade wind intensification and Trade-wind wave-induced mixing.

\section{Oxygen-Reduction Potential:}

Over the period of study, the oxygen-reduction potential at the site along the 3-m isobath ranged between $150.0 \mathrm{mV}$ and $397.2 \mathrm{mV}$, with a mean oxygen-reduction potential \pm one standard deviation of $289.2 \pm 50.6 \mathrm{mV}$. Oxygen-reduction potential had an inverse relationship with $\mathrm{pH}$ and the percentage of dissolved oxygen during the summer months, with oxygen-reduction potential decreasing during the daytime and increasing into the night, attaining it greatest values just before sunrise (FIGURES 910). However, during the winter months when temperature and salinity were more variable, oxygen-reduction potential had more variable positive relationship with $\mathrm{pH}$ and the percentage of dissolved oxygen, suggesting that changes in salinity due to precipitation and/or submarine groundwater discharge might be impacting the data.

\section{Vertical Variability:}

The temperatures during the vertical profiles taken in the early morning varied between $27.83^{\circ} \mathrm{C}$ and $28.72{ }^{\circ} \mathrm{C}$, with the near-surface temperatures on average roughly $0.74{ }^{\circ} \mathrm{C}$ warmer than the near-bed temperatures. The salinities during these profiles varied between $33.47 \mathrm{PSU}$ and 34.38 PSU, with the near-surface temperatures roughly 0.79 PSU less saline on average than the near-bed salinities. The dissolved oxygen levels during these profiles varied between $15.3 \%$ and $91.2 \%$, with the near-surface dissolved oxygen levels on average roughly $41.1 \%$ higher on average than the near-bed dissolved oxygen levels (FIGURE 11).

The temperatures during the vertical profiles taken in the late afternoon varied between $27.85^{\circ} \mathrm{C}$ and $29.51^{\circ} \mathrm{C}$, with the near-surface temperatures roughly $1.32{ }^{\circ} \mathrm{C}$ warmer on average than the near-bed temperatures. The salinities during these profiles varied between $33.21 \mathrm{PSU}$ and $34.35 \mathrm{PSU}$, with the near-surface temperatures roughly 0.91 PSU less saline on average than the near-bed salinities. The dissolved oxygen levels during these profiles varied between $11.7 \%$ and $104.4 \%$, with the near-surface dissolved oxygen levels roughly $46.6 \%$ higher on average than the near-bed dissolved oxygen levels (FIGURE 11). 

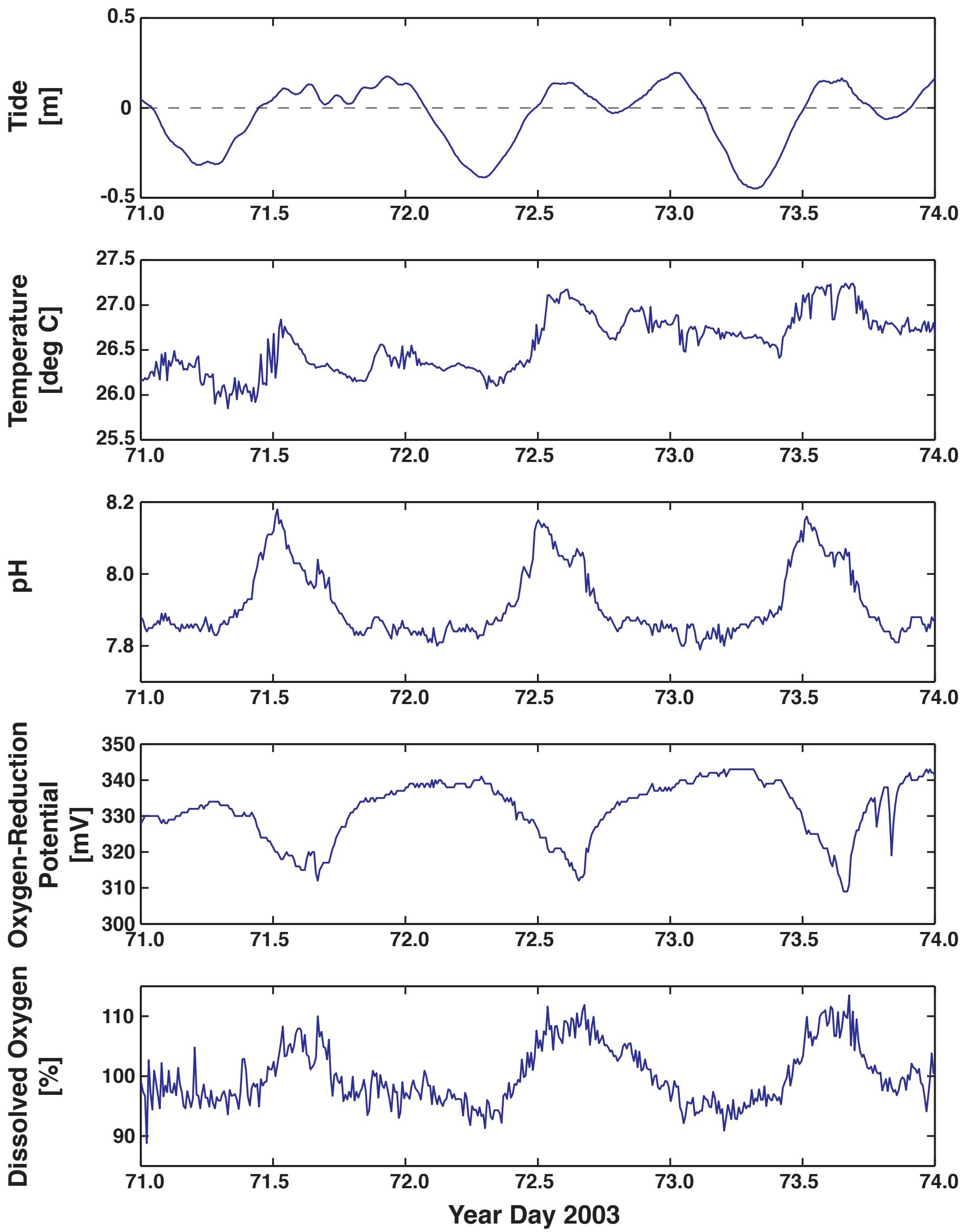

FIGURE 9. Phasing between tides and near-surface $(3 \mathrm{~m})$ temperature, $\mathrm{pH}$, oxygen-reduction potential and dissolved oxygen. Note the shallow water temperature, $\mathrm{pH}$ and dissolved oxygen tend to increase during the day into the early afternoon and then decrease in the late afternoon into the early morning. Oxygen-reduction potential acts exactly opposite, attaining its lowest levels in the early afternoon and its highest levels by the early morning. 

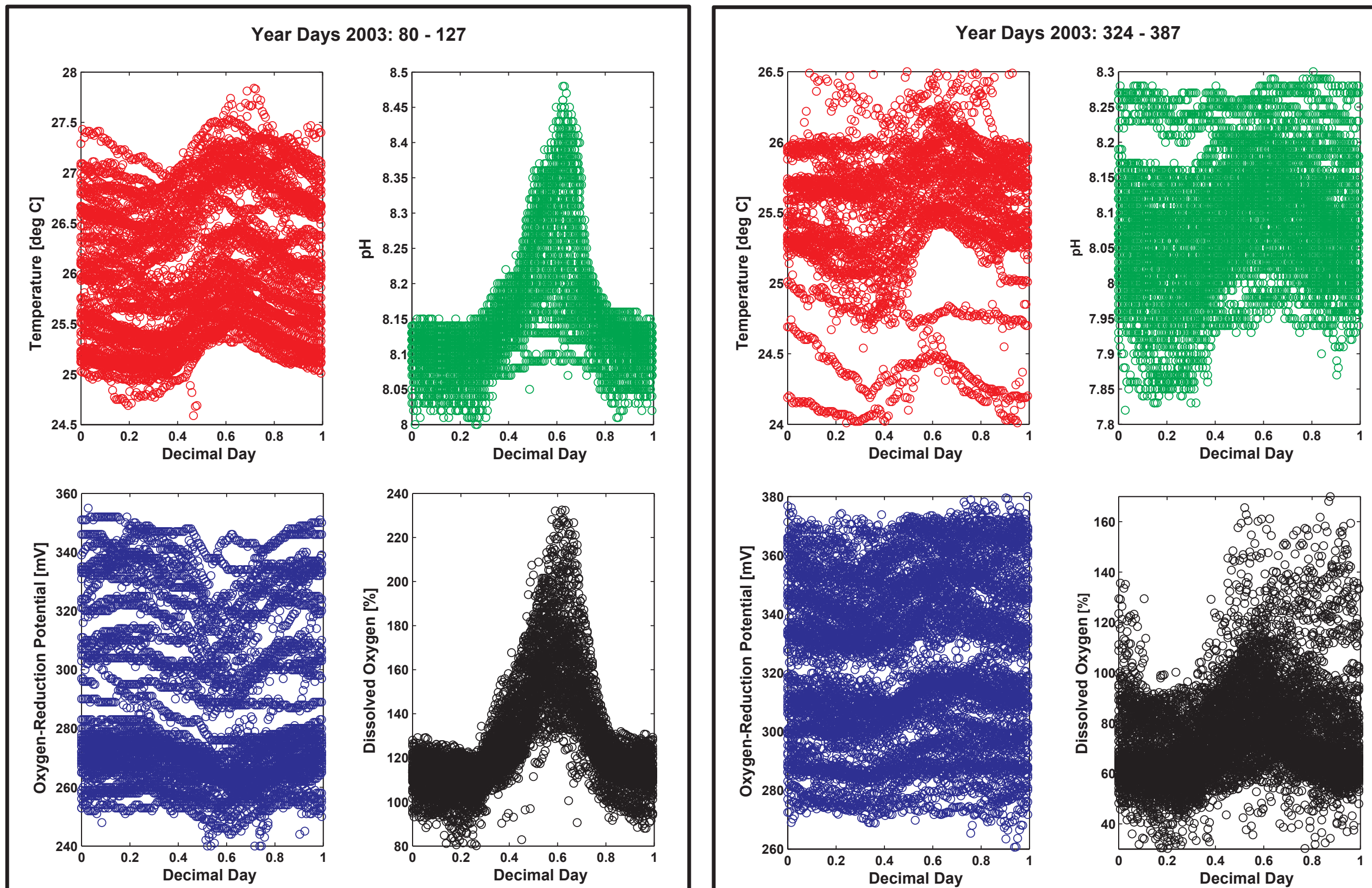

FIGURE 10. Phasing of temperature, $\mathrm{pH}$, oxygen-reduction potential and dissolved oxygen relative to the time of day and by season. Temperature, $\mathrm{pH}$ and dissolved oxygen increase towards early afternoon and decline through the night into the early morning while oxygen-reduction potential shows the opposite behavior during the summer months (left panel). During the winter months when precipitation increases, temperature, pH, dissolved oxygen and oxygen-reduction potential are much more variable and increase towards early afternoon and decline through the night into the early morning, likely due to changes in salinity (right panel). 
Fall AM Casts

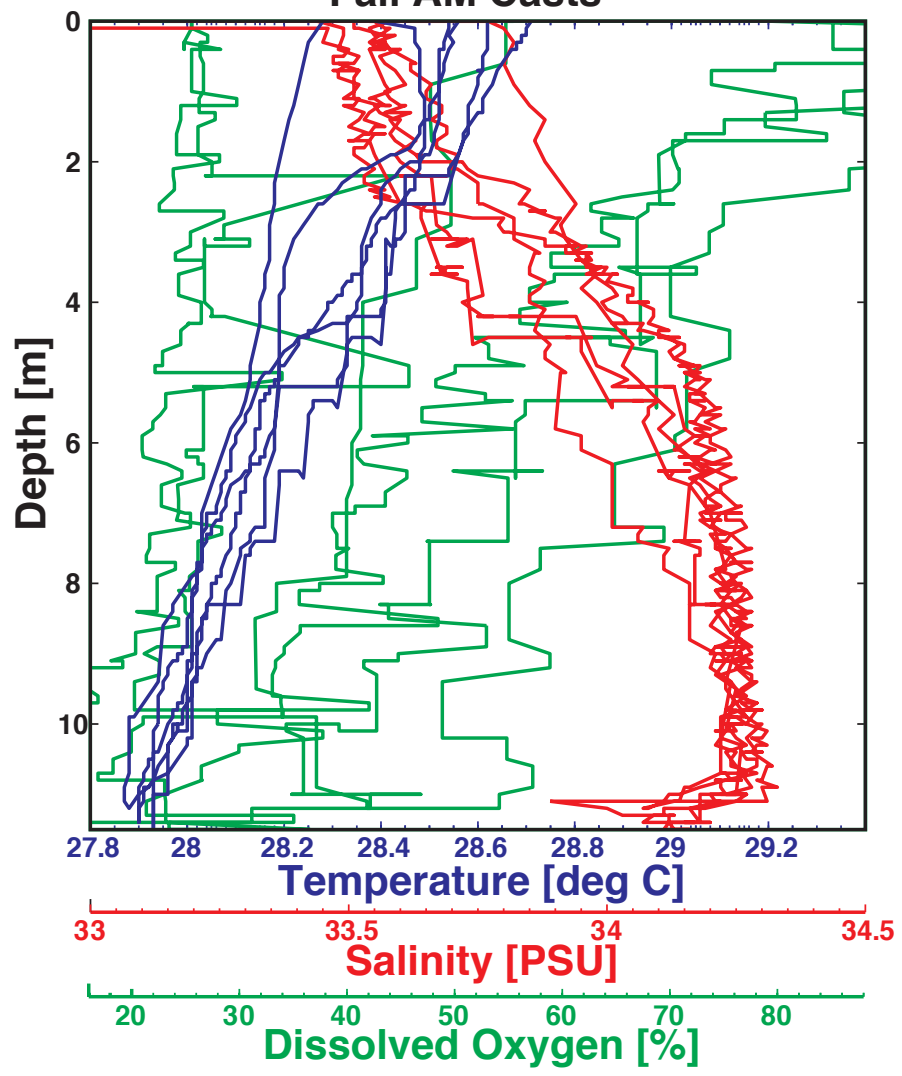

Fall PM Casts

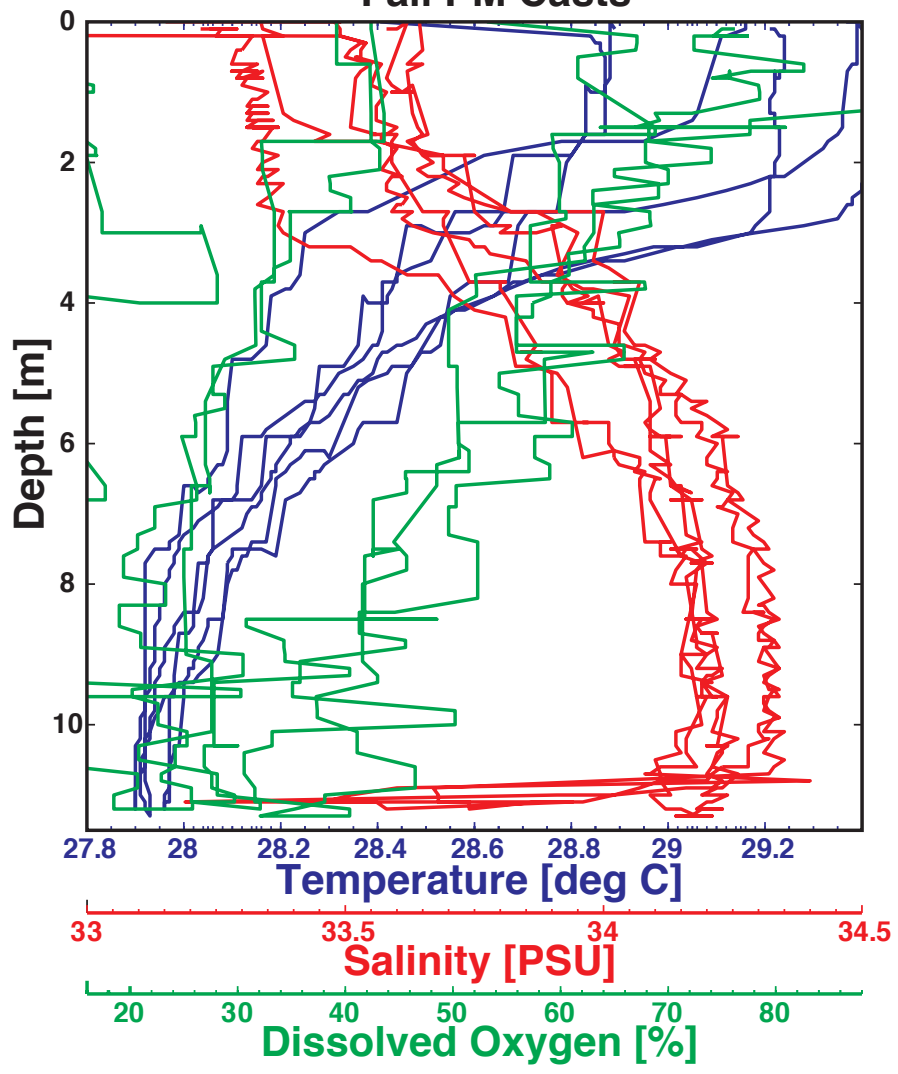

Fall AM Casts - Average

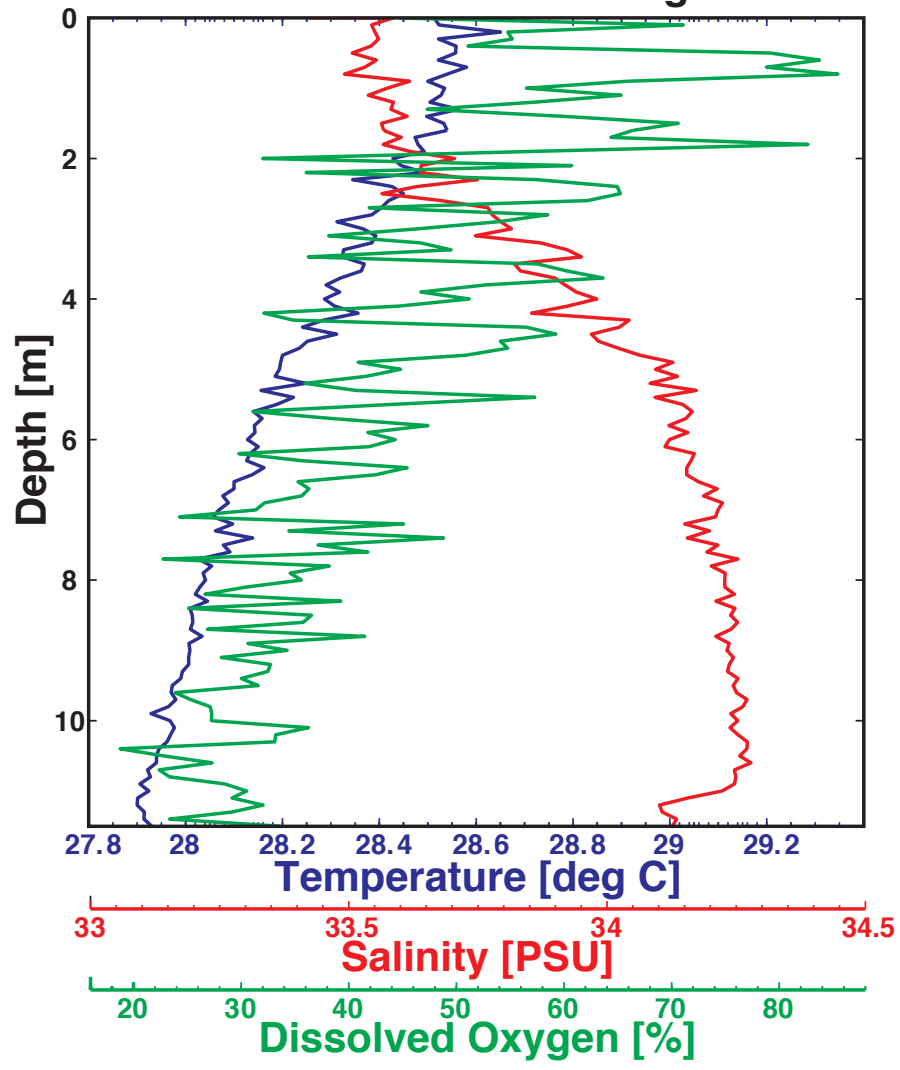

Fall PM Casts - Average

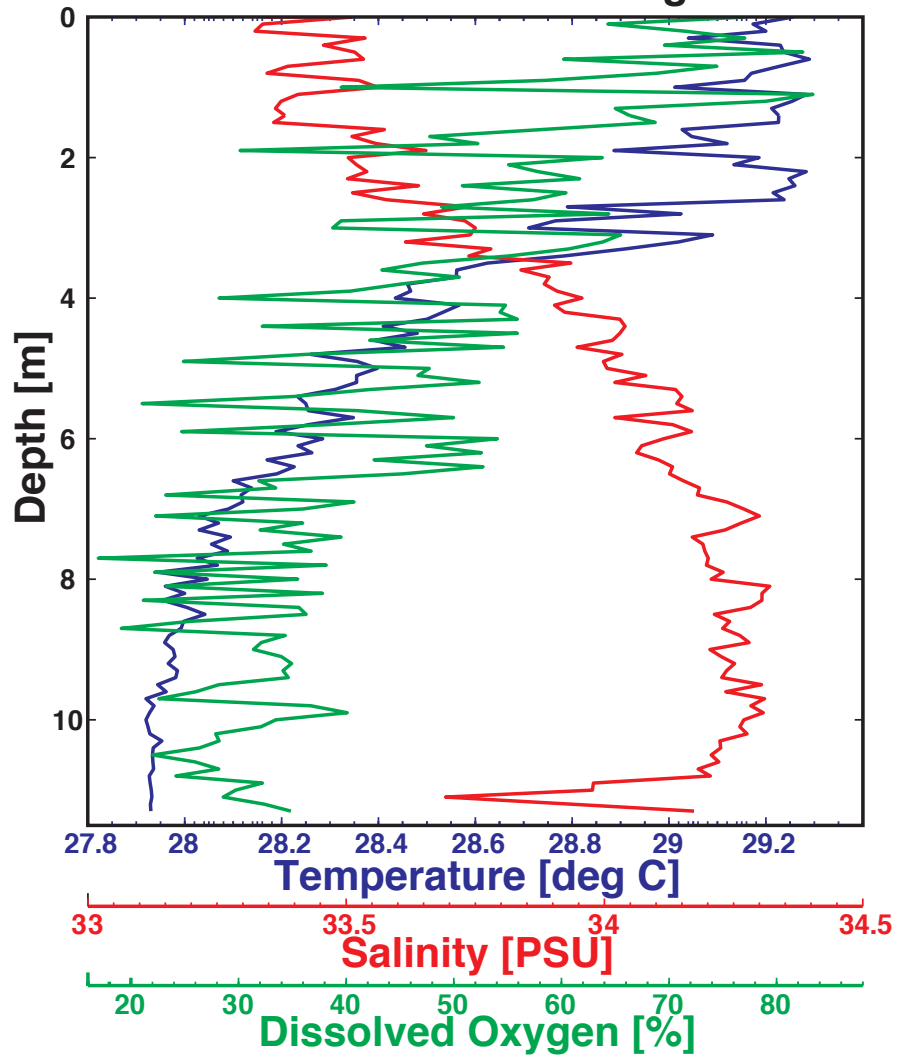

FIGURE 11. Vertical profiles of temperature, salinity and dissolved oxygen off the USAR dock. These plots show how these parameters vary vertically from just below the water's surface down to the sea floor and how the vertical variation in these parameters changes over the course of a day. 
While mean near-bed temperatures did not vary significantly between the early morning and late afternoon vertical profiles, it is quite apparent that not only did the mean near-surface water temperatures increase significantly, but that a thermocline stretching to $6 \mathrm{~m}$ below the surface warmed on average approximately $0.8^{\circ} \mathrm{C}$. Neither salinity nor dissolved oxygen showed significant variations in the mean vertical profiles taken in the early morning versus those taken in the late afternoon.

\section{CONCLUSIONS}

In all, more than 503,730 observations of currents, waves and water-column properties were collected per day for 362 days over the course of 14 months between November 2002 and January 2004 in Pearl Harbor, Oahu, Hawaii, USA. Significant findings based upon these measurements and analyses include:

(1) Tides are of mixed, semi-diurnal type with a minimum, mean and maximum tidal range of $0.4 \mathrm{~m}, 0.6 \mathrm{~m}$ and $0.9 \mathrm{~m}$, respectively.

(2) Waves are not an important factor in the vicinity of Arizona's hull. Those observed were, while long period ( $20 \mathrm{sec}$ ), very small (order of $\mathrm{cm}$ 's) and likely due to open ocean long-period swell. Vessels passing close to the study site are likely responsible for the high-amplitude, low-period motions that were observed.

(3) Flow along the 10-m isobath is dominated by semi-diurnal and diurnal tidal motions, which are modulated to some degree by what appears to be wind forcing during the mid- to late afternoon. Flow is primarily orthogonal to the Arizona's hull at $\sim 0.020 \mathrm{~m} / \mathrm{sec}$, and net flow is to the southeast, away from the hull at $\sim 0.002 \mathrm{~m} / \mathrm{sec}$.

(4) Acoustic backscatter was generally higher in the winter months and during the falling tide, suggesting advection of material introduced into the northern sections of Pearl Harbor due to winter precipitation and its movement south past the hull by ebbing tidal currents. Higher measurements of acoustic backscatter often occurred in the afternoon, suggesting increased Trade wind-induced mixing or, perhaps, increased vessel activity, which facilitates water column mixing and fine-grained particulate resuspension.

(5) Water temperatures were generally slightly higher (mean $=26.03^{\circ} \mathrm{C}$ ) and less variable (standard deviation $=1.17^{\circ} \mathrm{C}$ ) along the $10-\mathrm{m}$ isobath than along the 3$\mathrm{m}$ isobath $\left(\right.$ mean $=24.55^{\circ} \mathrm{C}$, standard deviation $=2.08^{\circ} \mathrm{C}$ ). A thermocline was often present in the harbor's waters, with the shallower $(3 \mathrm{~m})$ and deeper $(10 \mathrm{~m})$ water temperatures often differing by more than $2{ }^{\circ} \mathrm{C}$.

(6) Salinity ranged from 16.78 PSU and 42.56 PSU, with a mean \pm one standard deviation of $34.33 \pm 4.25$ PSU. Salinity appears to positively correlate with water temperature and suggests that Pearl Harbor's waters are influenced by freshwater runoff or groundwater effluence in the winter months. 
(7) $\mathrm{pH}$ ranged between 7.60 and 9.10 , with a mean \pm one standard deviation of 8.04 \pm 0.15 and dissolved oxygen $0 \%$ and $288.5 \%$, with a mean \pm one standard deviation of $69.5 \pm 58.8 \%$. Both $\mathrm{pH}$ and dissolved oxygen tended to correlate with the daily insolation cycle, increasing during the morning into the early afternoon followed by decreasing through the night to minimum levels just before sunrise.

(8) Oxygen-reduction potential ranged between $150.0 \mathrm{mV}$ and $397.2 \mathrm{mV}$, with a mean \pm one standard deviation of $289.2 \pm 50.6 \mathrm{mV}$. Oxygen-reduction potential had an inverse with $\mathrm{pH}$ and the percentage of dissolved oxygen during the summer months and a positive relationship with $\mathrm{pH}$ and the percentage of dissolved oxygen during the winter months when temperature and salinity were more variable.

(9) During the vertical profiling, near-surface temperatures were on average roughly $1.03^{\circ} \mathrm{C}$ warmer than the near-bed temperatures, near-surface temperatures were roughly $0.85 \mathrm{PSU}$ less saline on average than the near-bed salinities and near-surface dissolved oxygen levels were on average roughly $43.9 \%$ higher than the near-bed dissolved oxygen levels.

These data provide us with a much clearer picture of the nature of and controls on the physical environment around USS Arizona's hull in Pearl Harbor, Oahu, Hawaii. The complexity of the physical environment surrounding and influencing Arizona is reflected in the number of interesting phenomena observed during this initial 14-month study. The next step is to correlate these environmental aspects with active processes affecting Arizona to refine the predictive model of the ship's deterioration.

\section{ACKNOWLEDGEMENTS}

This work was carried out as part of a NPS-USGS partnership as part of an effort in the U.S. and its trust territories to better understand and characterize the nature of and variability in coastal processes. NPS-SRC Chief Larry Murphy, USGS Western Regional Director Doug Buffington and Western Regional Geologist Michael Carr deserve thanks for providing us with the patience, opportunity and support to carry out these deployments. Joshua Logan (USGS) assimilated the NPS GIS data and produced the maps presented in this report. We would also like to thank Ann Gibbs (USGS) and Carissa Carter (USGS), who contributed numerous excellent suggestions and a timely review of our work. 
TABLE 1. Experiment personnel

\begin{tabular}{|l|l|l|}
\hline \multicolumn{1}{|c|}{ Person } & \multicolumn{1}{|c|}{ Affiliation } & \multicolumn{1}{c|}{ Responsibilities } \\
\hline Curt Storlazzi & USGS & Chief scientist, scuba diver \\
Matthew Russell & NPS-SRC & Co-chief scientist, led scuba diving operations \\
Marshall Owens & NPS-USAR Memorial & USAR Memorial curator, led refurbishment operations \\
Michael Field & USGS & Scientist, scuba diver \\
Larry Murphy & NPS-SRC & Scientist, scuba diver \\
Michael Freeman & NPS-USAR Memorial & Scuba diver \\
\hline
\end{tabular}

TABLE 2. Instrument package deployment log: 11/2002 - 01/2004

\begin{tabular}{|l|c|c|c|c|c|c|}
\hline Instrument & Island ID & Depth $(\mathrm{m})$ & Date Deployed & Date Recovered & Latitude (dd) & Longitude (dd) \\
\hline Sontek Triton & OA & 10 & $11 / 21 / 02$ & $01 / 30 / 03$ & 21.36415 & -157.95054 \\
Sontek Triton & OA & 10 & $01 / 30 / 03$ & $03 / 07 / 03$ & 21.36415 & -157.95054 \\
YSI 6600 Sonde & OA & 3 & $01 / 30 / 03$ & $03 / 07 / 03$ & 21.36494 & -157.94986 \\
Sontek Triton & OA & 10 & $03 / 21 / 03$ & $05 / 07 / 03$ & 21.36415 & -157.95054 \\
YSI 6600 Sonde & OA & 3 & $03 / 21 / 03$ & $05 / 07 / 03$ & 21.36494 & -157.94986 \\
Sontek Triton & OA & 10 & $05 / 15 / 03$ & $07 / 02 / 03$ & 21.36415 & -157.95054 \\
Sontek Triton & OA & 10 & $07 / 08 / 03$ & $08 / 29 / 03$ & 21.36415 & -157.95054 \\
Sontek Triton & OA & 10 & $08 / 29 / 03$ & $10 / 10 / 03$ & 21.36415 & -157.95054 \\
YSI 6600 Sonde & OA & 3 & $08 / 29 / 03$ & $10 / 10 / 03$ & 21.36415 & -157.95054 \\
Sontek Triton & OA & 10 & $10 / 23 / 03$ & $11 / 05 / 03$ & 21.36415 & -157.95054 \\
YSI 6600 Sonde & OA & 3 & $10 / 24 / 03$ & $11 / 20 / 03$ & 21.36494 & -157.94986 \\
Sontek Triton & OA & 10 & $11 / 20 / 03$ & $01 / 13 / 04$ & 21.36473 & -157.95081 \\
YSI 6600 Sonde & OA & 3 & $11 / 20 / 03$ & $01 / 22 / 04$ & 21.36494 & -157.94986 \\
\hline
\end{tabular}




\section{APPENDIX 1}

\section{SonTek Triton Information}

Instrument:

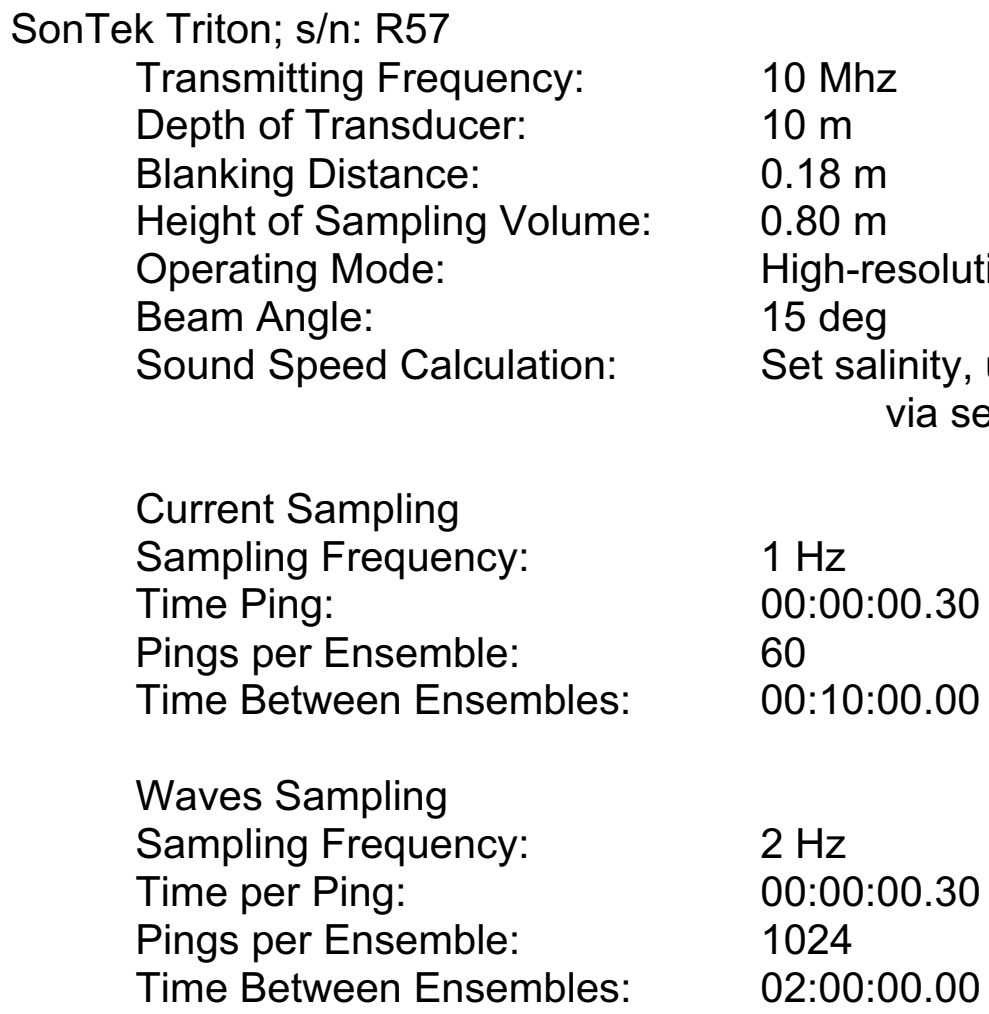

Total Files: 7

Data Processing:

The data were averaged over 1 hour ( 6 ensembles) and all of the data where the beam correlation dropped below $70 \%$ were removed for visualization and analysis. 


\section{APPENDIX 2}

\section{YSI 6600 Sonde Information}

Instruments:

YSI 6600 Sonde; s/n: 02g0147

Initial Height of Measurement above Bed:

Sampling Frequency:

Samples per Ensemble:

$0.25 \mathrm{~m}$

Time Between Ensemble:

$2 \mathrm{~Hz}$

60

00:10:00.00

Total Files: 5

Data Processing:

The data were averaged over 1 hour ( 6 ensembles) and all of the data where the beam correlation dropped below $70 \%$ were removed for visualization and analysis. 